\title{
Moderate to Severe Cancer Pain: Are We Taking Serious Action? The Opioid Prescribing Scenario in Portugal
}

\section{Dor Oncológica Moderada a Intensa: Estamos a Tomar Medidas Concretas? O Cenário do Consumo de Opioides em Portugal}

Paulo REIS-PINA $\rrbracket^{1,2}$, Peter G. LAWLOR ${ }^{3,4}$, António BARBOSA $2,5,6$

Acta Med Port 2018 Sep;31(9):451-453 - https://doi.org/10.20344/amp.10999

\section{INTRODUCTION}

Pain is one of the most feared and distressing symptoms associated with cancer. ${ }^{1}$

In Portugal, the incidence of malignant tumors has been increasing regularly, according to the 2017 National Program for Oncological Diseases. ${ }^{2}$ In 2016, cancer was the second basic cause of death in Portugal, representing $24.7 \%$ of mortality. ${ }^{3}$

Recently, a Portuguese study showed that of 371 patients with cancer-related pain (CRP), $77 \%$ had moderate to severe pain, whose severity could be explained by the lower morphine equivalent daily dose prescribed. ${ }^{4}$ Moreover, undertreatment of CRP was present in $25.6 \%$ of patients. ${ }^{5}$ There was an association between inadequacy of CRP treatment and absence of opioid prescriptions $(p<$ 0.001). ${ }^{5}$
\end{abstract}

Keywords: Analgesics, Opioid; Cancer Pain; Pain Management; Pain Measurement

Palavras-chave: Analgésicos Opióides; Avaliação da Dor; Controlo da Dor; Dor Oncológica

\section{ACCESS TO ADEQUATE PAIN TREATMENT}

Uncontrolled pain is a major public health concern. People with CRP ought to have access to appropriate pain assessment and treatment by adequately trained health care professionals. ${ }^{1,6}$

The Declaration of Montreal states that access to pain management is a fundamental human right. Withholding pain treatment is profoundly wrong, leading to unnecessary suffering which is harmful. ${ }^{7}$

According to the World Health Organization, in its 2011 guidance document 'Ensuring balance in national policies on controlled substances', governments should ensure that all population groups, without discrimination, equally benefit from their policies on the availability and accessibility of controlled medicines for rational medical use. That has been established in Portugal. Some historical milestones confirm that. In 2003, the Directorate-General of Health safeguarded pain as the $5^{\text {th }}$ vital sign and its assessment became mandatory. In 2004, the Portuguese Medical Association approved the 'Competence in Pain Medicine' and, in 2013, likewise, a 'Competence in Palliative Medicine' was agreed. In 2011, the Portuguese Ministry of Health launched Law 113/2011 announcing that all the consultations at Pain Clinics within the National Health Service were free of charge. In 2013, the National Strategic Pain Prevention and Control Plan was approved. In 2016, the legislation entitled Portaria 331/2016 declared a new list of WHO-step III analgesics, reimbursable up to $90 \%$, to be used in ambulatory patients with CRP. ${ }^{8}$ In 2017, the new National Programme for the Prevention and Control of Pain was launched.

\section{OPIOID CONSUMPTION IN PORTUGAL}

Opioids are the pillar of the medical management of moderate to severe CRP. ${ }^{6}$

Although extremely high rates of use of opioids exist in a few countries, namely in the USA, it should not be regarded as an ubiquitous problem. ${ }^{9}$

Despite overcoming legislative impediments to availability, opioid consumption $(\mathrm{OC})$ in Portugal is ranked among the lowest in western Europe. ${ }^{10}$

There is a certain form of morphinofobia in Portugal. ${ }^{11}$ Potential causes of undertreatment of CRP, which are attributable to health care providers, are both the fear of prescribing opioids and the lack of knowledge concerning optimal pain management. ${ }^{6}$ That was implied in a crosssectional study aiming at exploring the significance and attitudes concerning the use of morphine, with 412 Portuguese participants (physicians and nurses) working at different settings (four hospitals and 10 community health centers). ${ }^{11}$ It showed that 'morphine' firstly suggested 'analgesia' to only $32.9 \%$ of professionals. The reasons for

\footnotetext{
1. Palliative Care Unit. Casa de Saúde da Idanha. Sintra. Portugal.

2. Faculdade de Medicina. Universidade de Lisboa. Lisbon. Portugal.

3. Bruyère Research Institute. Bruyère Continuing Care. Ottawa Hospital Research Institute. The Ottawa Hospital. Ottawa. Ontario. Canada.

4. Division of Palliative Care. Department of Medicine. University of Ottawa. Ottawa. Ontario. Canada.

5. Department of Psychiatry. Centro Hospitalar Lisboa Norte. Lisbon. Portugal.

6. Centre of Bioethics \& Palliative Care Studies Division. Faculdade de Medicina. Universidade de Lisboa. Lisbon. Portugal.

$\triangle$ Autor correspondente: Paulo Reis-Pina. preispina@hotmail.com

Recebido: 29 de junho de 2018 - Aceite: 17 de julho de 2018 | Copyright @ Ordem dos Médicos 2018
} 
not using morphine were fear both of legal risks $(56.3 \%)$ and of adverse side effects, such as somnolence-sedation $(30.5 \%){ }^{11}$

In a nationwide study, which included a representative sample of the Portuguese adult population (5094 participants), the prevalence of OC in chronic pain was $4.37 \%$ (95\% confidence interval $=3.4-5.5)$, being $10.13 \%$ and $4.24 \%$ in cancer and non-cancer patients, respectively. ${ }^{9}$ Strong opioids were prescribed to $0.17 \%$ of the patients. Pain severity was significantly associated with OC, however in multivariate modeling only pain-related disability remained associated to OC. ${ }^{9}$

A Portuguese prospective observational study with 301 advanced cancer patients referred to palliative care showed that $74 \%$ were on opioids, $42 \%$ had moderate to severe and $35.2 \%$ had no pain at all. It found that moderate to severe CRP was associated with shorter time to death. ${ }^{12}$ Sample characteristics in the latter study were quite different from the ones found in the previously mentioned crosssectional Portuguese observational study 4,5 : patients were ambulatory, CRP was present in $100 \%, 83.3 \%$ had good performance status and $88.7 \%$ were on opioids, yet more than $2 / 3$ of the sample still had moderate to severe CRP. Prescribed opioids were weak $(73.3 \%)$, mainly tramadol, and rarely strong ones $(15.4 \%) .{ }^{5}$ This was odd because firstly, patients were followed at a national cancer center; secondly, because in cancer patients low-dose morphine reduces pain intensity significantly compared with weak opioids, with a similar good tolerability and an earlier effect. ${ }^{13}$ The role of tramadol is limited in moderate to severe CRP. ${ }^{14}$

The Pain \& Policy Studies Group, a WHO Collaborating Center, receives from the International Narcotics Control Board consumption data for six principal opioids used to treat moderate to severe pain. ${ }^{10}$ These data represent the amounts of opioids distributed for medical purposes to the 'retail' level in a country (i.e., to those institutions and programs that are licensed to dispense to patients, such as hospitals, nursing homes, pharmacies, hospices, palliative care programs, or medication assisted treatment programs). ${ }^{10}$ It combines $\mathrm{OC}$ both for cancer and noncancer pain, with no distinction between them.

Recent data showed that $\mathrm{OC}$ in Portugal, not considering methadone use, was 84.27 morphine equivalent (ME). ${ }^{10}$ This includes (in ME): morphine (4.46), oxycodone (1.06), fentanyl (70.94), hydromorphone (7.26) and pethidine (0.55).

For comparison purpose, in 2015, in Portugal, methadone use represented 97.87 ME, much more than other opioids, altogether, prescribed in the country. Methadone is a drug that has similar analgesic benefits to morphine and has a role in the management of CRP in adults. Other opioids such as morphine and fentanyl are more expensive than methadone, but they are far easier to manage. ${ }^{15}$ It is likely, that much, if not most, of the methadone in Portugal is used for medication assisted treatment of opioid dependence syndrome and, therefore, is not a good indication of a country's capacity to relieve pain. ${ }^{10}$

If we look at the global OC in Portugal, we end up with 182.13 ME. This is less than the figures found, excluding methadone, in southern countries like Spain, in western countries like the Netherlands and Switzerland, and in northern countries like Norway and Sweden. All of these have OC ranging from 215 and 265 ME (methadone not considered). ${ }^{10}$

In 2015, out of 24 European countries analyzed, there were only six with fewer OC (excluding methadone) than Portugal: Croatia, Montenegro, Albania, Estonia, Latvia and Lithuania. All of these have OC less than $39 \mathrm{ME}$. In the other 17 countries apart from Portugal OC varies from 125 ME (in Ireland) to 517.69 (in Germany). Southern countries like Italy, Greece and Spain have ME of 131.86, 155.31 and 233.58, respectively, all above the OC in Portugal. ${ }^{10}$

\section{CONCLUSION}

Opioid prescribing and CRP: is there an adequate relationship balancing between optimal use of potent analgesics and stable pain management? If you were to find a CRP undertreatment rate of $25.6 \%$ - in a sample of cancer patients with metastatic disease $(70.9 \%)$, on palliative treatment $(47.4 \%)$, suffering from moderate to severe pain $(77 \%)$, and dealing with depression $(75.5 \%)$ and anxiety $(70.6 \%)^{4,5}$ - what would you think about? Are we taking the bull by the horns? We sustain: there is still room for improvement.

\section{REFERENCES}

1. Lawlor PG, Lawlor NA, Reis-Pina P. The Edmonton Classification System for Cancer Pain: a tool with potential for an evolving role in cancer pain assessment and management. Expert Rev Qual Life Cancer Care. 2018;3:47-64.

2. Ministério da Saúde. Direção-Geral da Saúde. Programa Nacional para as Doenças Oncológicas 2017. Setembro 2017. [acedido 2018 jun 29]. Disponível em: https://www.dgs.pt/portal-da-estatistica-da-saude/ diretorio-de-informacao/diretorio-de-informacao/por-serie-880762-pdf. aspx?v=11736b14-73e6-4b34-a8e8-d22502108547.

3. Instituto Nacional de Estatística, I.P. Causas de morte 2016. Lisboa: INE; 2016. [acedido 2018 jun 29]. Disponível em: https://www.ine.pt/ xportal/xmain?xpid=INE\&xpgid=ine_publicacoes\&PUBLICACOESpub_ boui $=320385399 \&$ PUBLICACOESmodo $=2$.

4. Pina P, Sabri E, Lawlor PG. Characteristics and associations of pain intensity in patients referred to a specialist cancer pain clinic. Pain Res

Manag. 2015;20:249-54.

5. Reis-Pina P, Lawlor PG, Barbosa A. Adequacy of cancer-related pain management and predictors of undertreatment at referral to a pain clinic. J Pain Res. 2017;10:2097-107.

6. Reis-Pina P, Lawlor PG, Barbosa A. Cancer-related pain management and the optimal use of opioids. Acta Med Port. 2015;28:376-81.

7. International Association for the Study of Pain. International Pain Summit. Declaration of Montréal: declaration that access to pain management is a fundamental human right. J Pain Palliat Care Pharmacother. 2011;25:29-31.

8. Portaria 331/2016. Ministério da Saúde. Diário da República, 1 a $^{\text {a }}$ série, N. ${ }^{\circ} 244,22$ de dezembro de 2016. [acedido 2018 jun 29]. Disponível em: https://dre.pt/application/file/a/105595660.

9. Azevedo LF, Costa-Pereira A, Mendonça L, Dias CC, Castro-Lopes JM. A population-based study on chronic pain and the use of opioids in 
Portugal. Pain. 2013;154:2844-52.

10. Pain \& Policy Studies Group; WHO Collaborating Center. Opioid consumption maps. Morphine equivalence minus methadone, mg/ capita, 2015. Madison: Carbone Cancer Center; School of Medicine and Public Health; University of Wisconsin. [acedido 2018 jun 29]. Disponível em: https://ppsg.medicine.wisc.edu/.

11. Verloo H, Mpinga EK, Ferreira M, Rapin $\mathrm{CH}, \mathrm{Chastonay} \mathrm{P.} \mathrm{Morphinofobia:}$ the situation among the general population and health care professionals in North-Eastern Portugal. BMC Palliat Care. 2010;9:15.

12. Barata P, Santos F, Mesquita G, Cardoso A, Custódio MP, Alves M, et al.
Pain intensity and time to death of cancer patients referred to palliative care. Acta Med Port. 2016;29:694-701.

13. Bandieri E, Romero M, Ripamonti Cl, Artioli F, Sichetti D, Fanizza C et al. Randomized trial of low-dose morphine versus weak opioids in moderate cancer pain. J Clin Oncol. 2016;34:436-42.

14. Wiffen PJ, Derry S, Moore RA. Tramadol with or without paracetamol (acetaminophen) for cancer pain. Cochrane Database Syst Rev. 2017;5:CD012508.

15. Nicholson AB, Watson GR, Derry S, Wiffen PJ. Methadone for cancer pain. Cochrane Database Syst Rev. 2017;2:CD003971. 